\title{
19. INTERSTITIAL WATER STUDIES, LEG 33
}

\author{
Joris M. Gieskes, Scripps Institution of Oceanography, La Jolla, California
}

\begin{abstract}
Interstitial water analyses carried out on samples retrieved during Leg 33 indicate that post-burial diagenetic processes influence the chemistry of the interstitial fluid significantly. Increases in dissolved strontium and dissolved silica reflect recrystallization of carbonate and dissolution and recrystallization of opaline silica. Changes in dissolved sulfate and ammonia are interpreted in terms of bacterial sulfate reduction processes. Dissolved calcium and magnesium changes in the rapidly deposited upper carbonate oozes and chalks may indicate either carbonate diagenesis or alteration of basaltic material interspersed in these sediments. The chemistry of the interstitial waters retrieved from the volcanogenic sediments is very different from that of the overlying carbonate sediments. This can be explained in terms of relative isolation from the overlying sediment column by the low permeability chalk-chert layers and the reactivity of the volcanogenic sediments. Low dissolved potassium and magnesium values in the basal sediments indicate uptake of these elements in the volcanogenic sediments or in the chalk-chert layers separating the basal sediments from the carbonate sections. Dissolved calcium values in the basal sediments indicate ongoing alteration processes in these sediments and/or in the underlying basalts. An analysis is made of the significance of sedimentation rates with respect to observed changes in the chemistry of the interstitial waters.
\end{abstract}

\section{INTRODUCTION}

Studies of interstitial waters recovered during the Deep Sea Drilling Project have often revealed large changes in the composition of the dissolved constituents with depth in the sediment column. Among the major aims of these studies is the possible detection of authigenic reactions, which occur after deposition of the sediments and are not likely to be detected in the solid phases (Manheim and Sayles, 1974; Sayles and Manheim, 1975). Inferences from changes in the interstitial water chemistry about possible diagenetic reactions have generally not been substantiated. For instance, concentration changes in dissolved calcium and magnesium at Sites 70-72 (Leg 8, DSDP) have been interpreted by Sayles and Manheim (1975) in terms of carbonate diagenesis. Based on oxygen isotope data on the interstitial waters of these sites, however, Lawrence et al. (in press) argue that the changes in dissolved magnesium and calcium may be related to alteration reactions in basalts underlying the sediments at these sites. A detailed chemical and mineralogical analysis of sediments and interstitial waters recovered from Site 245 (Leg 25, DSDP) in the Madagascar Basin led Gieskes et al. (in press) to the conclusion that basaltic material in the basal sediments and the underlying basalt sill still undergo alteration leading to magnesium uptake from the interstitial waters and a simultaneous increase in dissolved calcium. The search for reaction products in the sediments is not an easy one, but it must nonetheless be pursued for a more complete interpretation of the diagenetic processes in the sediment column.
During Leg 33, several sites were drilled with a potentially interesting sedimentary sequence from the point of view of a further study of the processes that lead to observed concentration changes in the interstitial waters. Most of the sites drilled during Leg 33 are characterized by thick, rapidly deposited carbonate sediments, underlain by volcanogenic sediments, Cretaceous in age. At two sites (315 and 317) basaltic basement was reached.)Sediment accumulation rates are presented in Figure 1.

The present report concerns itself mainly with the results of the analyses of the composition of the interstitial waters recovered from Leg 33 sites. Some tentative interpretations will be presented which are based on available mineralogical and lithological information (see Site Reports, this volume, as well as the article by Cook and Zemmels, this volume). Also, some specialized studies appear in this volume that have relevance to the interstitial water data: that on cherts by Kelts, and that on bulk sediment chemistry of Site 317 by Donnelly and Wallace.

Mechanisms suggested in the present report, of course, should be verified, and we intend to follow this up in future work.

\section{METHODS}

Interstitial waters were collected using the routine shipboard squeezing techniques described by Manheim and Sayles (1974). Small amounts of the squeezed samples were used for the measurement of salinity (refractometer), of $p \mathrm{H}$, and of alkalinity (colorimetric). For the analysis of alkalinity also, 5- or 10-ml samples 


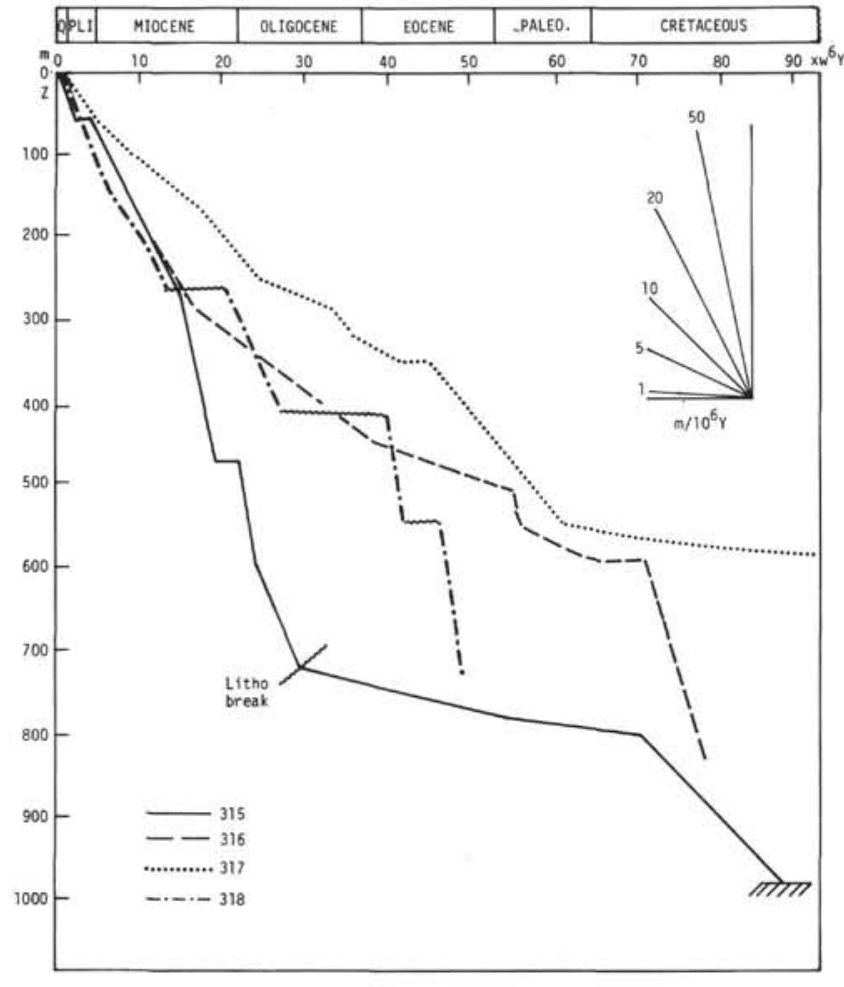

Figure 1. Sedimentation rate diagram, Leg 33.

were titrated with $0.1 \mathrm{~N} \mathrm{HCl}$, using the potentiometric technique described by Gieskes and Rogers (1973). These titrated samples were subsequently stored in sealed polyethylene vials for future analysis of other constituents. Sediments obtained in the deeper parts of the sites yielded very little, if any, interstitial water, and these samples were analyzed only for salinity, $p \mathrm{H}$, and sometimes alkalinity. Data on dissolved ammonia may have been affected by storage, although decomposition of this component is retarded in an acidified medium (Gieskes, 1974).

As I was particularly interested in obtaining interstitial water samples close to basalt basement, i.e., in the volcanogenic sediments, I obtained small amounts of sediment which had been stored about 14 months in the DSDP core locker. These small samples $(10-20 \mathrm{ml})$ yielded sometimes as much as $0.5-1.0 \mathrm{ml}$ of interstitial water, on which a fairly complete chemical analysis could be made. Previously we have shown in my laboratory with stored samples of Leg 10 (Gieskes, 1973) that interstittal water data obtained immediatnly after recovery of samples c uld be reproduced using sedimen that had been stored for as $\log$ as $2 \mathrm{yr}$. Similar findings were made on sediment from Site 253 (Russell McDuff, personal communication). Data on $\mathrm{Ca}^{++}$, $\mathrm{Mg}^{++}, \mathrm{Sr}^{++}, \mathrm{K}^{+}$, and $\mathrm{SO}_{4}{ }^{--}$could be reproduced after minor adjustment for a slight chlorinity increase. On this basis, therefore, we consider our chemical analyses obtained from these stored samples valid and representative of original conditions.

Analytical methods in this study have been described previously by Gieskes (1974). Small modifications have been made wherever appropriate.

\section{RESULTS}

The data obtained in this study are tabulated in Table 1. In addition, the data for some specific components are presented in Figures 2 to 11 .

Negative values for $\mathrm{Mg}^{++}$can be explained by the fact that we obtained $\mathrm{Mg}^{++}$by a difference method (Gieskes, 1974). Data are well within estimated accuracies.

\section{DISCUSSION}

It is clear from the data in Table 1 and Figures 2 to 11 that the four sites studied during Leg 33 are similar in their nature as far as their interstitial water chemistry is concerned. Sites 315 and 317, especially the latter, are the most completely studied, and I shall restrict the discussion mostly to these two sites. In the following I would like to discuss first the upper parts of these sites, i.e., the rapidly deposited carbonate oozes and chalks, and then the underlying volcanogenic units.

\section{Carbonate Oozes and Chalks}

The upper 500-600 meters of both Site 315 and Site 317 are characterized by rapidly deposited (Figure 1) carbonate oozes with $\mathrm{CaCO}_{3}$ contents usually $90 \%$ or higher and organic carbon contents ranging between $0.02 \%$ and $0.1 \%$ (Cameron, this volume). Both sites show very slight increases in alkalinity (Figures 2 and 7) and decreases in dissolved sulfate (Figure 4). these observations could reflect the bacterial reduction of sulfate (Sayles and Manheim, 1975; Gieskes, 1973, 1974). For this reason, it is of some interest to inspect the dissolved ammonia profiles (Figure 5). Although the data show some scatter and it is possible that some ammonia may have been lost upon storage (see Methods section), it is apparent that dissolved $\mathrm{NH}_{4}+$ is indeed much higher at Site 315 than at Site 317, reflecting the larger sulfate decrease at Site 315. Sholkovitz (1973) found an increase in $\mathrm{NH}_{4}{ }^{+}$of $1000 \mu$ moles/1 for a sulfate decrease of 10 $\mu$ moles $/ 1$ in the rapidly deposited sediments of the Santa Barbara Basin. Comparison with the data presented in Figures 4 and 5 makes it most plausible, therefore, that sulfate decreases are bacterially induced. Indeed, pyrite has been reported at Site 315 (Cook and Zemmels, this volume), but much of this material has probably been formed near the sediment-water interface. The slight increases in dissolved ammonia near the sediment-water interface (Figure 5) appear real, although there appears to be no clear explanation for this at present. It is of some interest to note that bacterial processes appear to be active after deep burial $(>300 \mathrm{~m})$ in the sediments. Of course, similar observations have been made previously in more rapidly deposited nearshore sediments (Gieskes, 1973, 1974; Sayles and Manheim, 1975). It would be of some interest to make some bacteriological studies in such sediments to identify the organisms responsible for these processes.

In view of the data obtained on dissolved ammonia, I favor the explanation of the sulfate depletion due to bacterial sulfate reduction processes, rather than by the precipitation of barite. This mineral is reported throughout the carbonate sections of these sites (Zemmels and Cook, this volume). The latter explanation cannot be dismissed a priori because, upon the dissolution of siliceous microfossils (cf, high dissolved 
TABLE 1

Interstitial Water Composition

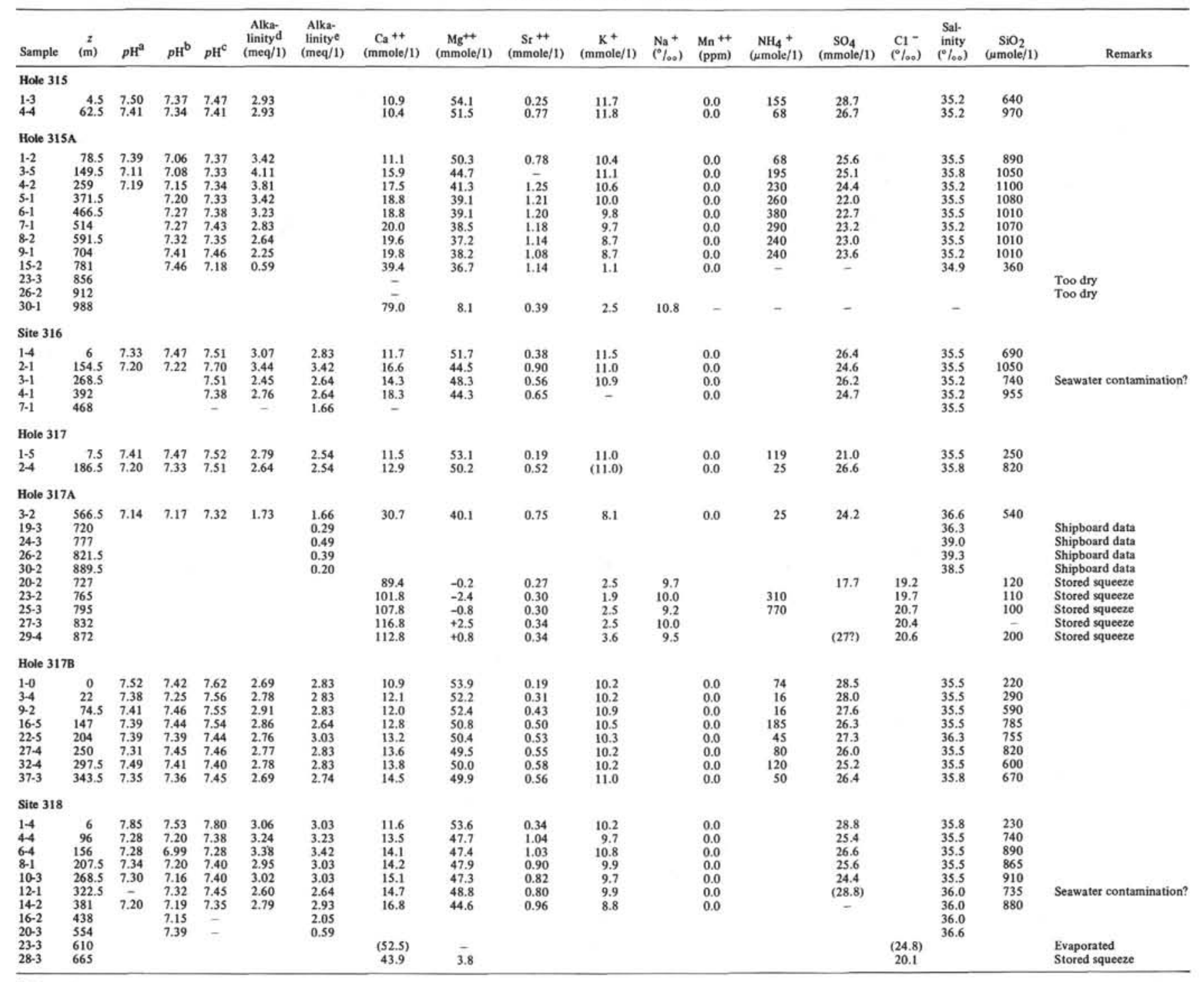

${ }^{2} \mathrm{pH}$ punch in.

$\mathrm{b}_{\mathrm{pH}}$ flow through.

${ }_{p \mathrm{H}}$ titration vessel.

dAlkalinity EMF.

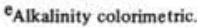

silica values, Table 1, Figure 10) and the recrystallization of carbonate fossils (cf, dissolved strontium values, Figures 3 and 8), some $\mathrm{Ba}^{++}$will definitely be set free into the solution and the solubility product of $\mathrm{BaSO}_{4}$ will be easily reached. Church and Wolgemuth (1972) indicate that only a doubling of the $\mathrm{Ba}^{++}$concentration is needed in Pacific deep water to reach the saturation ratio value with respect to pure barite. In addition, slight alkalinity increases could, in principle, result from dissolution of the dissolved strontium component upon recrystallization of calcium carbonate. For instance, dissolved strontium values at Site 315 (Figure 3) are much higher than at Site 317 (Figure 8), as is the maximum value in alkalinity (Figure 2 versus Figure 7).

The upper 500-600 meters of Sites 315 and 317 (as well as the other two sites, cf, Figures 6 and 11) reveal in- creases in dissolved calcium and decreases in dissolved magnesium, as well as large increases in dissolved $\mathrm{Sr}^{++}$. The latter values reflect the recrystallization of calcium carbonate. The dissolved $\mathrm{Sr}^{++}$cannot simply be due to calcium carbonate dissolution, as could be reflected by the dissolved calcium increase, because $\mathrm{Sr} / \mathrm{Ca}$ rations in pelagic carbonate oozes usually are about $10-20 \times 10^{-4}$ (molar ratio), as is pointed out by Sayles and Manheim (1975) and Gieskes et al. (in press). Extensive recrystallization must have occurred to reach these high dissolved strontium values. Decreases in $\mathrm{Mg}^{++}$and increases in $\mathrm{Ca}^{++}$have often been explained in terms of dolomite formation during calcium carbonate recrystallization (cf, Sayles and Manheim, 1975). If this is so, the question may be raised as to why, upon such extensive recrystallization, only relatively little dolomite 


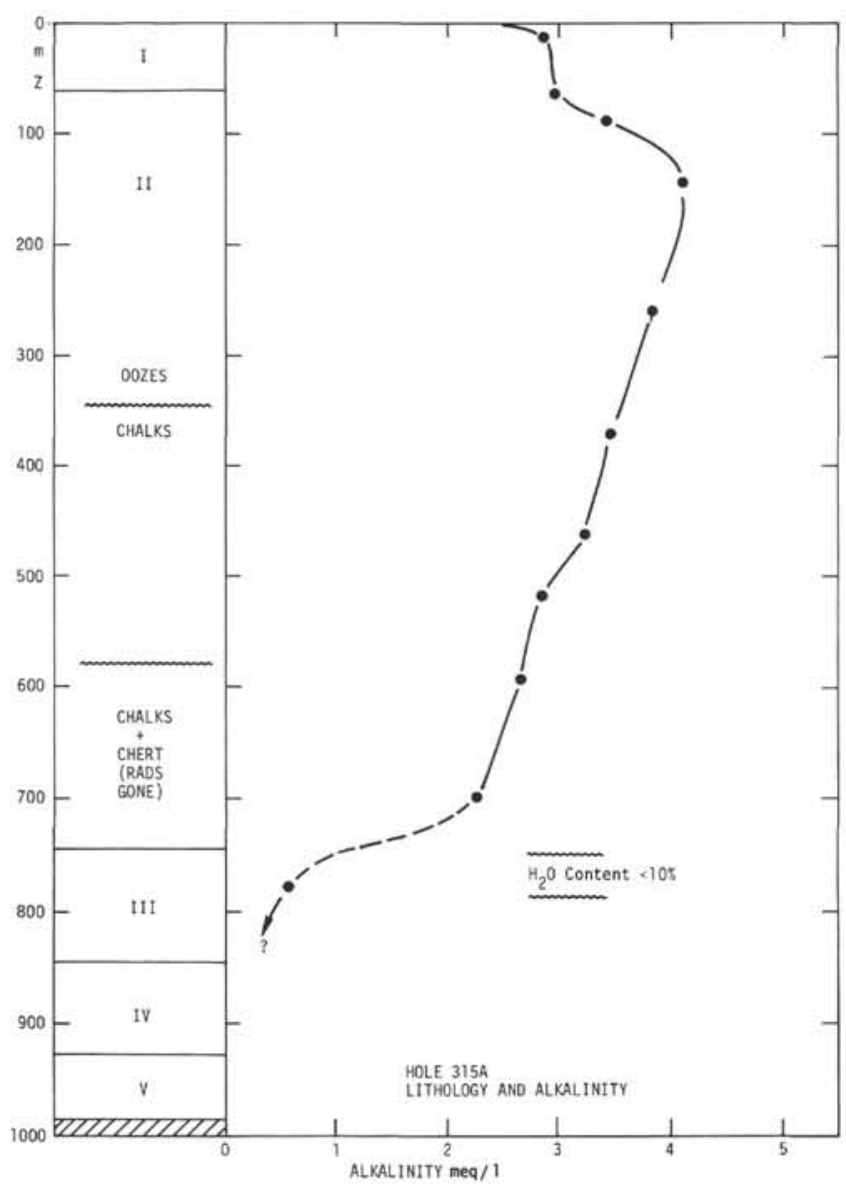

Figure 2. Lithology and alkalinity, Hole 315A. I= cyclic white and brown foram-nanno ooze and radiolarian nanno ooze; $I I=$ nanno-foram oozes and chalks; $I I I=$ claystone, lime packstones, and cherts; $I V=$ volcaniclastic sandstones and claystones; $V=$ ferrugenous claystones and volcaniclastic sandstones.

would form, compared with the total amount of carbonate recrystallized. At Site 315 , the loss of $\mathrm{Mg}^{++}$is larger than the gain in $\mathrm{Ca}^{++}$. The excess loss in $\mathrm{Mg}^{++}$is about equal to the sulfate loss, which is explained by Sayles and Manheim (1975) by the uptake of $\mathrm{Mg}^{++}$in nonexchangeable positions in clay minerals. This explanation has not been substantiated and should not be accepted as the only explanation.

In all sites of Leg 33, the presence of volcanic glass and of palagonite has been noticed. In addition, Ti/Al ratios at Site 317 (Donnelly and Wallace, this volume) are indicative of the presence of basaltic material in these calcareous oozes. Also, the latter authors report a general decrease in the $\mathrm{Mg} / \mathrm{Ca}$ ratio with depth in Site 317. Dolomitization would lead to an opposite trend. I offer an alternative explanation for the decreases in $\mathrm{Mg}^{++}$and increases in $\mathrm{Ca}^{++}$in the continued alteration of basaltic material in the sediments. A similar conclusion was reached in studies on sediments of Site 245 (Gieskes et al., in press). Differences in the ratio $\Delta \mathrm{Ca}^{++} / \Delta \mathrm{Mg}^{++}(\Delta=$ change in concentration $)$ could be explained in terms of mass balances. Dissolved calcium could come from the basaltic material, and con-

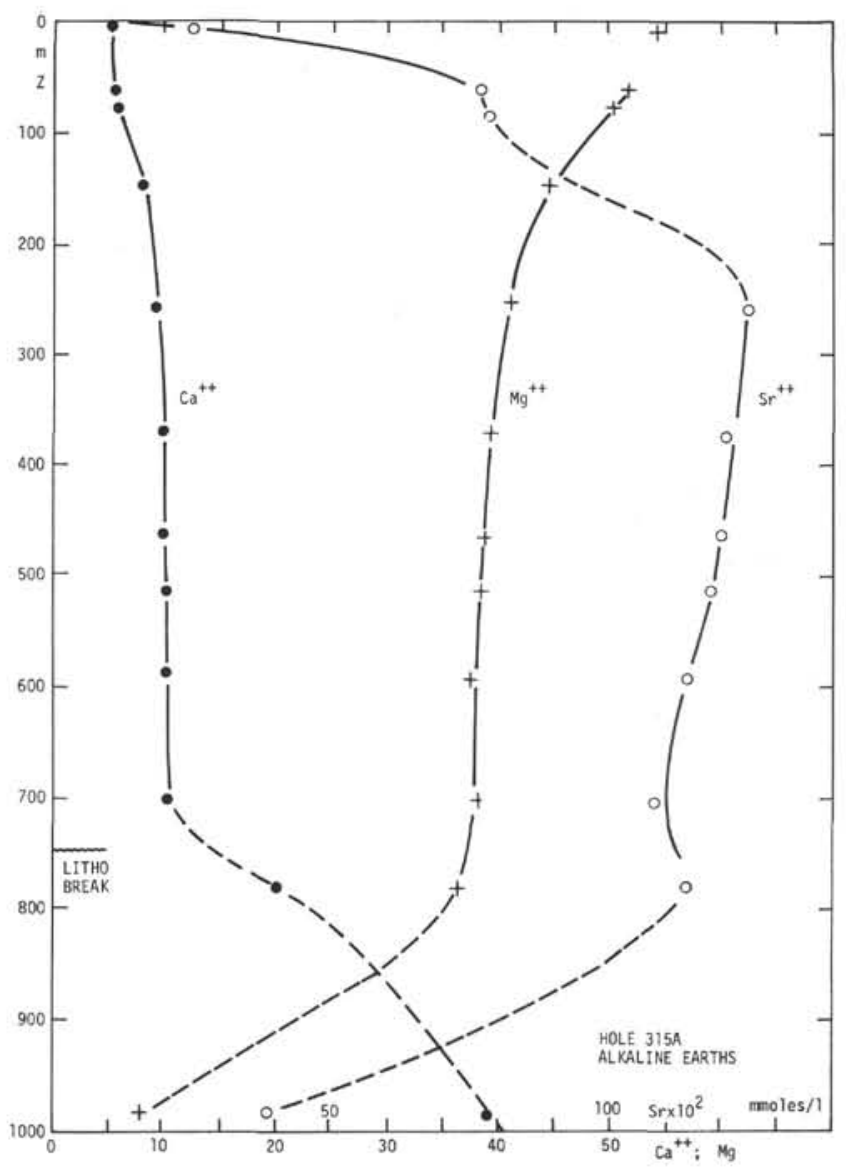

Figure 3. Alkaline earths, Hole $315 \mathrm{~A}$.

centrations could be controlled by carbonate equilibria in the interstitial waters.

Some of the above problems could be resolved by very careful studies of these sediments, including a search for dolomite and/or alteration products in the noncarbonate phases. Such studies are not simple in sediments with high calcium carbonate contents $(>90 \%)$. We plan some such studies to resolve some of the problems posed above.

\section{Volcanogenic Sediments}

The only sites drilled during Leg 33 reaching igneous basement were Sites 315 and 317 . At the base of each rapidly deposited calcium carbonate ooze, there appears a zone of cherts and dolomitic chalks that are characterized by very low rates of deposition and water contents of less than $10 \%$ (by weight). No interstitial waters could be recovered from these units, as sediments of such low water contents do not release any water. For these reasons, we shall not further consider these sedimentary sections, except for the observation that these sediment layers must have extremely low permeability and, hence, will constitute very efficient barriers against diffusional communication between the underlying volcanogenic units and the overlying chalks, which are both characterized by higher porosities.

The efficiency of the above-mentioned diffusional barrier is best demonstrated by the data on Site 317 


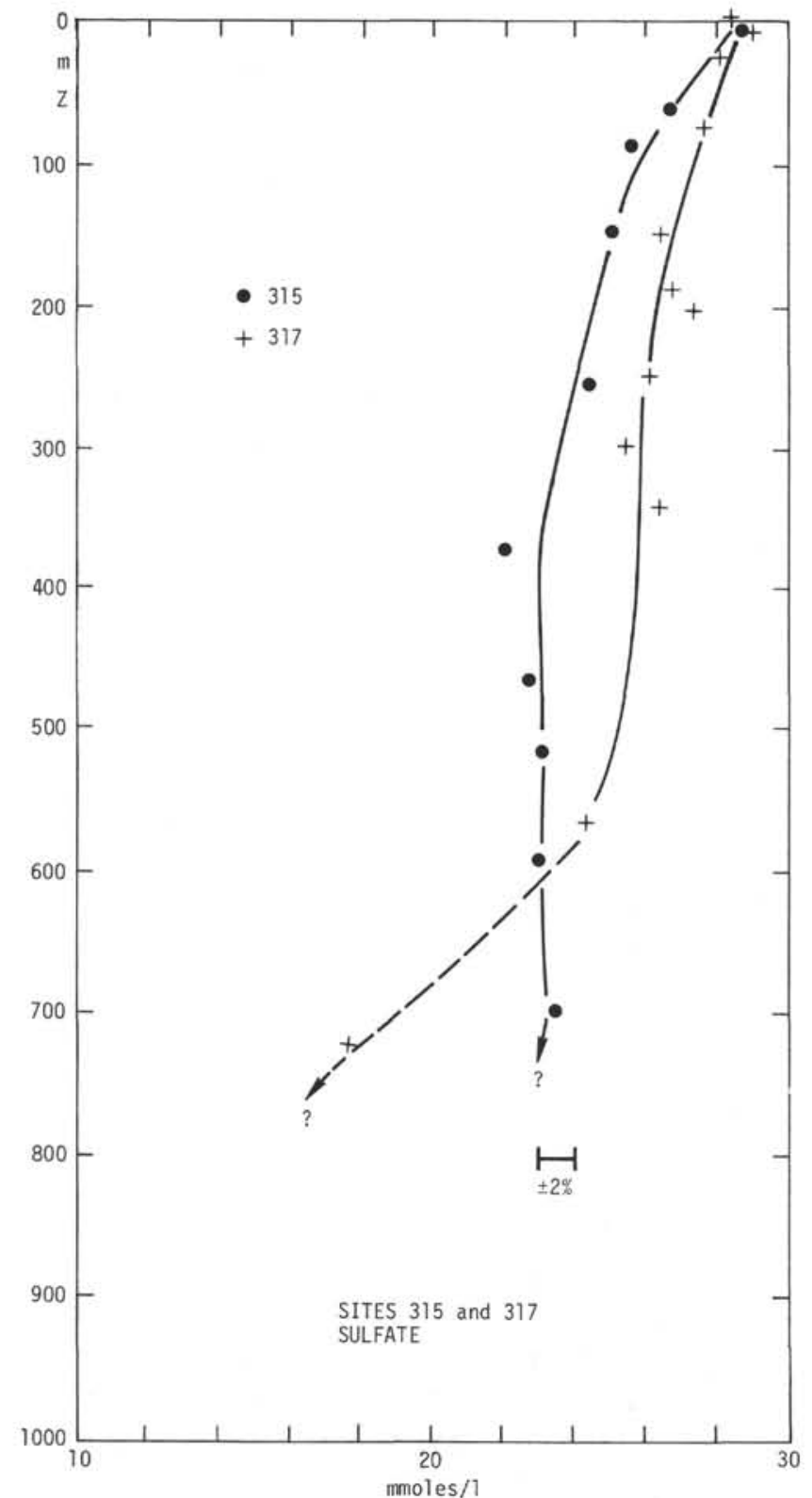

Figure 4. Sulfate, Sites 315 and 317.

(Figures 7 and 8). At 569 meters, dissolved $\mathrm{Ca}^{++}$and $\mathrm{Mg}^{++}$show increased curvature, but below the lithological break, dissolved $\mathbf{M g}^{++}$is zero and dissolved $\mathrm{Ca}^{++}$and $\mathrm{Sr}^{++}$are also very different from the above sediments. Of course, the dotted lines are somewhat fictitious, but they are probably reasonable interpolations. Clearly, the suggested diffusion barrier is not $100 \%$ effective, but it is sufficiently efficient to allow dissolved magnesium to disappear quantitatively from the interstitial waters in the volcanogenic sediments. If diffusional supply occurs from above, as is suggested by the profile, the rate of uptake of $\mathrm{Mg}^{++}$is sufficiently high to remove such supplied $\mathrm{Mg}^{++}$from the pore fluids. This removal could occur in the chert layers but equally well in the reactive volcanogenic sediments. Dissolved $\mathrm{K}^{+}$values reach a constant value of about 2.5 mmoles/1, again suggesting removal of $\mathrm{K}^{+}$in the chert



Figure 5. Ammonia, Sites 315 and 317.

zones or in the volcanogenic basal sediments. If $\mathrm{Mg}^{++}$ and $\mathrm{K}^{+}$uptake were to occur in the unsampled chert and chalk zones, larger gradients might be expected in the upper sediment strata. On this basis, I suggest that the most likely sinks for these elements are situated in the lower parts of the chert layers or in the basal sediments. Both elements show a uniform concentration in these strata, $\mathrm{Mg}^{++}$being zero and $\mathrm{K}^{+}$about 2.5 mmoles/1. Dissolved $\mathrm{Sr}^{++}$and $\mathrm{Ca}^{++}$, on the other hand, show increases in these sediments. In addition, salinities and chlorinities show increases of $6 \%-10 \%$. These increases are probably due to loss of water during the formation of hydrous aluminosilicates during the alteration of volcanic material or the underlying basalts. Dissolved calcium increases are probably due to such alteration reactions, which typically can release $\mathrm{Ca}^{++}$to pore solutions (Muffler et al., 1969; Bass et al., 1973). Notwithstanding the slight but apparently real increase in dissolved $\mathrm{Sr}^{++}$, I feel that calcium carbonate dissolution (no calcite reported) is an unlikely source for these $\mathrm{Sr}^{++}$and $\mathrm{Ca}^{++}$increases. Similar conclusions were reached by Sayles and Manheim (1975) for sites on the Ninetyeast Ridge. Unfortunately, sample sizes were too small to determine dissolved sulfate, but increased values of $\mathrm{NH}_{4}{ }^{+}$(cf, Figure 5, Table 1) suggest values of less than 10 mmoles/ 1 (compare also Figure 4). Dissolved $\mathrm{Na}^{+}$values decrease slightly, but the basal sediments do not appear to be significant sinks for this constituent. 


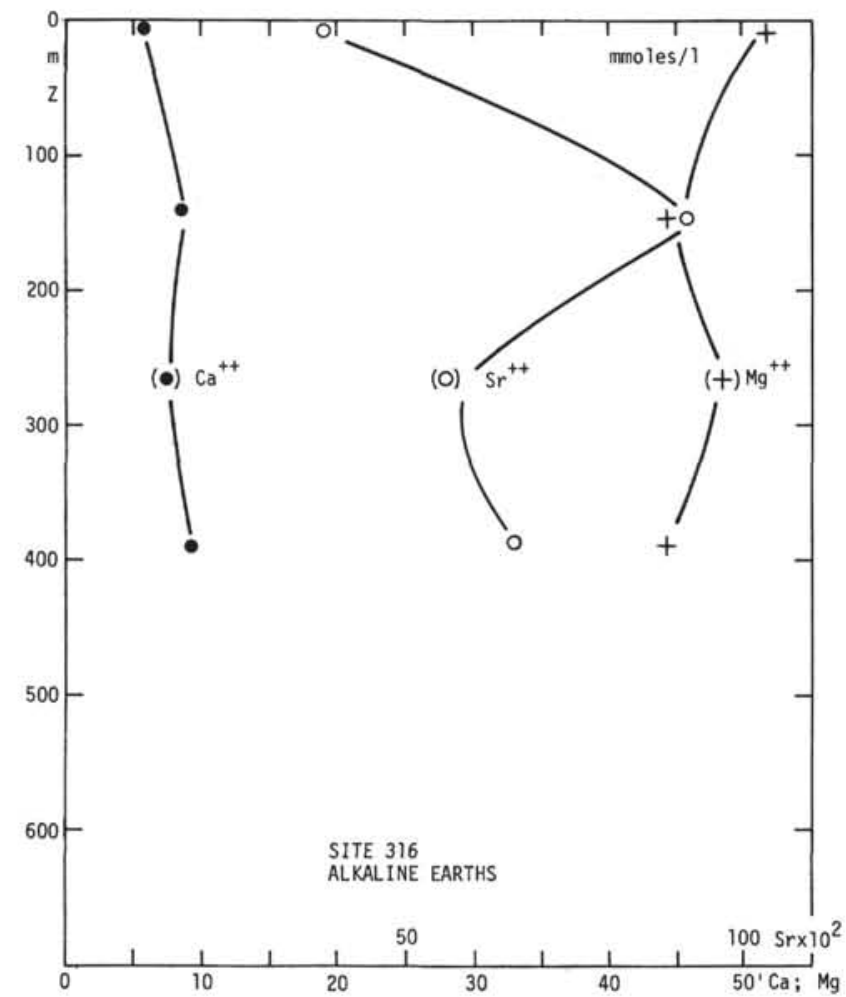

Figure 6. Alkaline earths, Site 316.

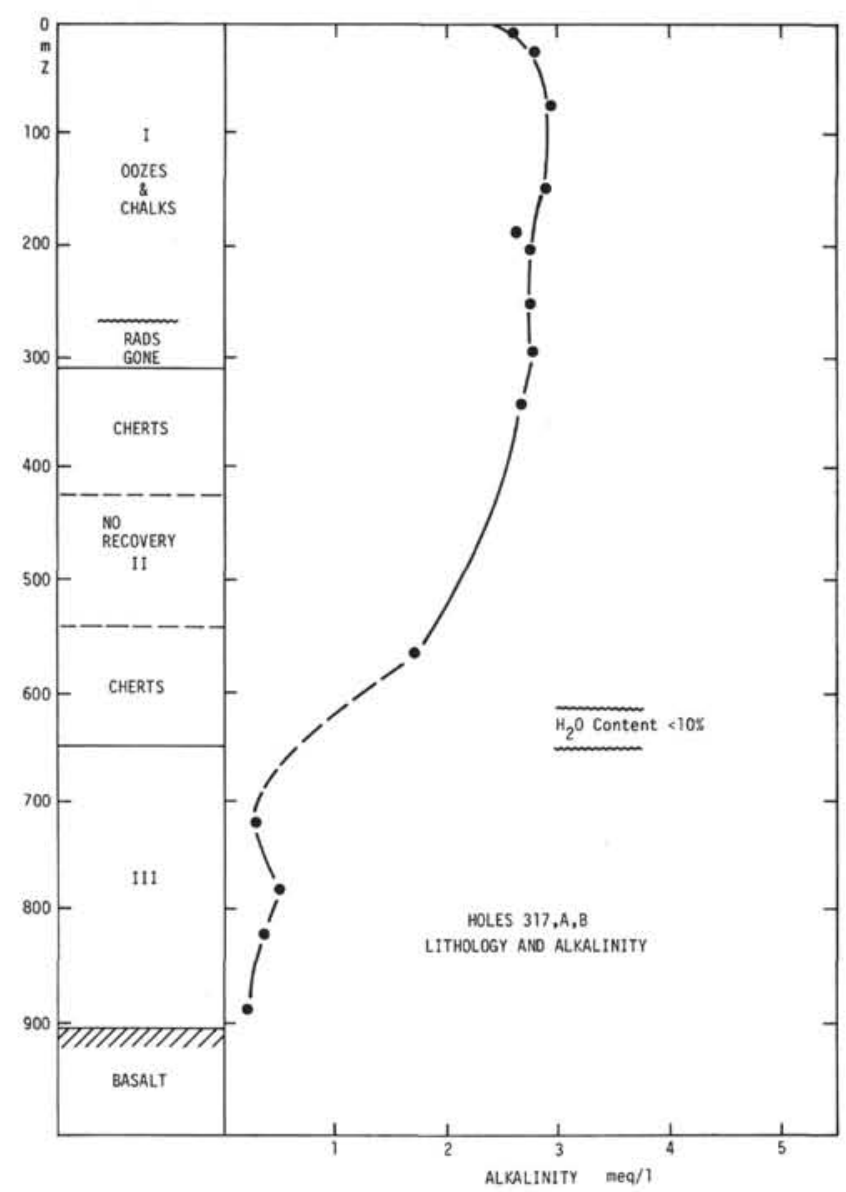

Figure 7. Lithology and alkalinity, Holes 317A, 317B. $I$ = gray-orange, white, and bluish-white nanno-foram oozes and chalks; $I I$ = foram-nanno oozes and chalks; $I I I=$ green-black volcanic sandstones; zeolites.

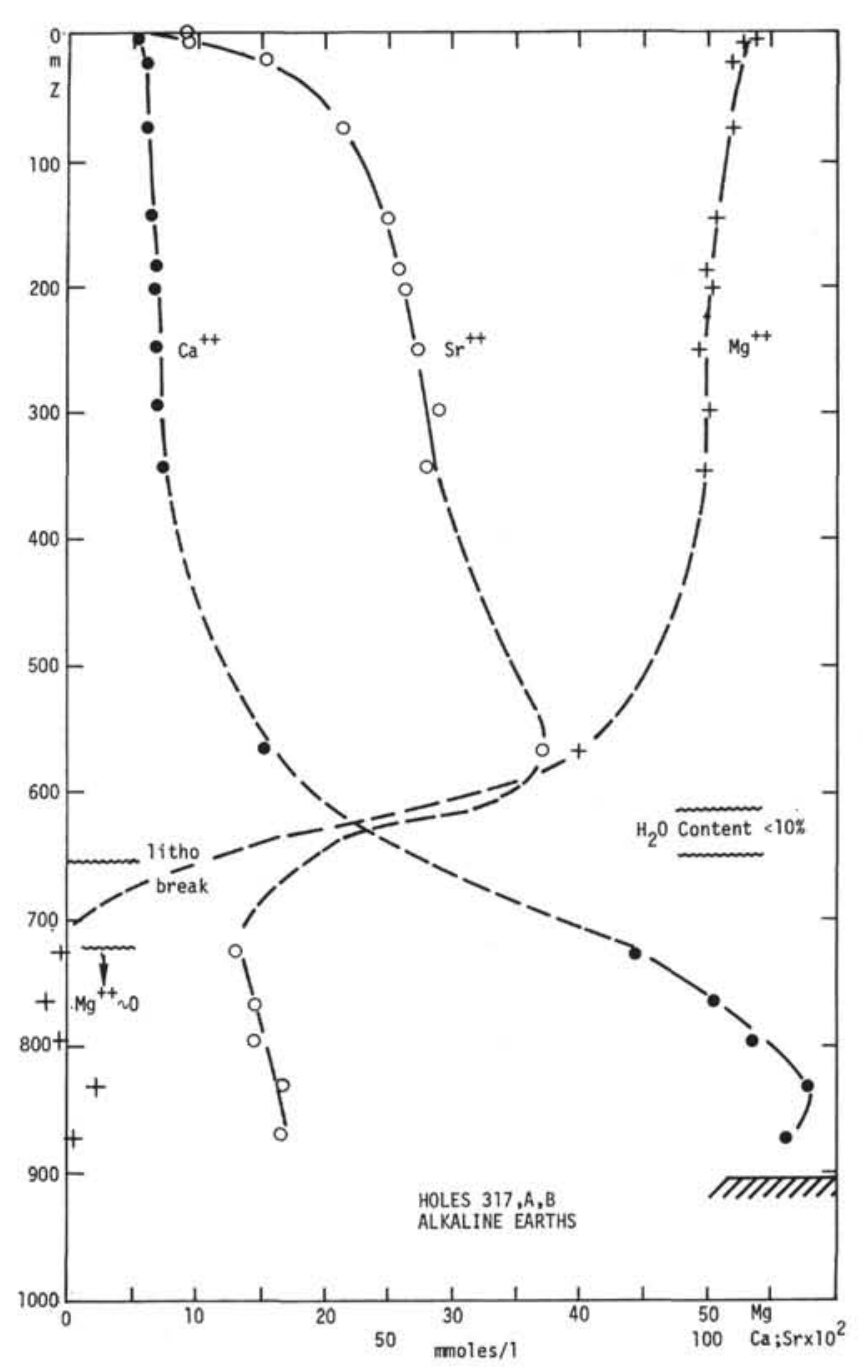

Figure 8. Alkaline earths, Site 317.

Although the cherts and chalk layers cannot be ruled out as important sinks for $\mathrm{Mg}^{++}$and $\mathrm{K}^{+}$, the volcanogenic sediments above the basalt can equally well serve as sinks for these elements. For $\mathrm{Sr}^{++}$and $\mathrm{Ca}^{++}$, these sediments appear to be a source, although I cannot rule out the possibility that the concentration gradients for the latter two elements are purely diffusional and are due to alteration reactions in the underlying basalts.

\section{Sedimentation Rates and Interstitial Water Profiles}

There appears to be a direct correlation between sedimentation rates and observed concentration changes in the interstitial fluids. In the following, I will consider only the rapidly deposited sediments in the upper parts of Sites 315,317 , and 318. Sedimentation rates are presented in Figure 1, with averages being: 2.7 (315), 0.9 (317), and $1.4 \mathrm{~cm} / 1000 \mathrm{yr}(318)$. In Figure 12, some of the concentration changes in the upper 400 meters are plotted as functions of the sedimentation rate. For each constituent, there appears a good correlation. The same is true for dissolved sulfate and dissolved silica. The latter averages $1050 \mu$ moles/1 at Site 315 , reaches a maximum of $800 \mu$ moles $/ 1$ at 317 , and averages 880 $\mu$ moles/ 1 at 318 . Sayles and Manheim (1975) attributed 


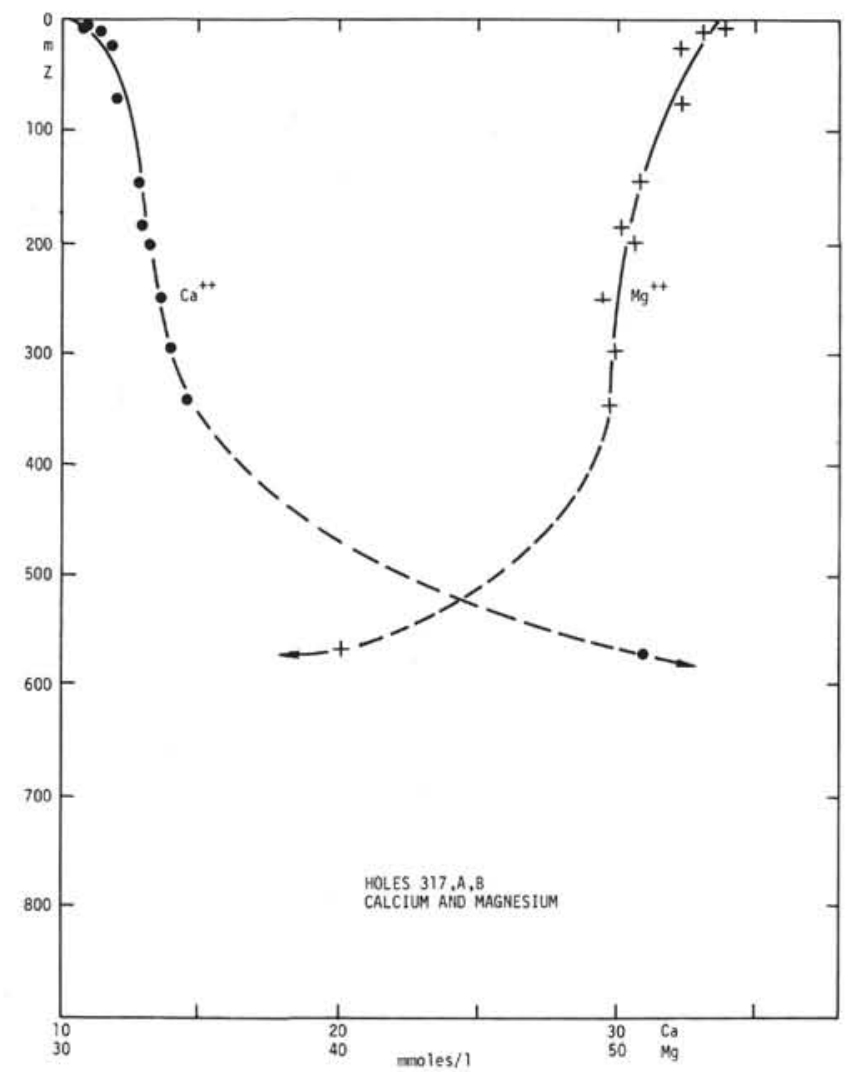

Figure 9. Calcium and magnesium, Site 317.

this to the presence of greater or lesser amounts of organic matter, greater amounts of this component in more rapidly deposited sediments presumably promoting larger rates of bacterial decomposition, which, in turn, promote diagenetic reactions and recrystallization of carbonates. Inspection of the data on organic carbon and calcium carbonate contents (Cameron, this volume) indicates similar levels of organic carbon at Sites 315 and 317 , whereas $\mathrm{CaCO}_{3}$ contents are lower in the more rapidly deposited sediments of Site 315 (90\% versus $95 \%$ in Site 317 ). These observations cast some doubt upon the deductions by Sayles and Manheim (1975). These authors also argue that the increases in $\mathrm{Sr}^{++}$are too large to be attributed only to the lower relative influence of diffusion in more rapidly deposited sediments. Such observations, of course, need extensive checks based on models taking into account different diffusion coefficients, different reaction rates, and considerations of sedimentation rates. Lerman (1975) considered diffusion-reaction models with average diffusion coefficients of $3 \times$ $10^{-6} \mathrm{~cm}^{2} / \mathrm{sec}$. With such relatively large diffusion coefficients, advective terms due to sedimentation rates can be ignored, but with values of $2 \times 10^{-6} \mathrm{~cm}^{2} / \mathrm{sec}$ (Gieskes et al., in press) or $1 \times 10^{-6} \mathrm{~cm}^{2} / \mathrm{sec}(\mathrm{Li}$ and Gregory, 1974), this assumption becomes less valid.

With regard to this, it may be instructive to compare the $\mathrm{Ca}^{++}$and $\mathrm{Mg}^{++}$profiles of Figures 3 and 8 or 9 . It appears that profiles at Site 315 reach a certain constancy, whereas at Site 317 the influence of the lower volcanogenic layers appears to be present to a somewhat

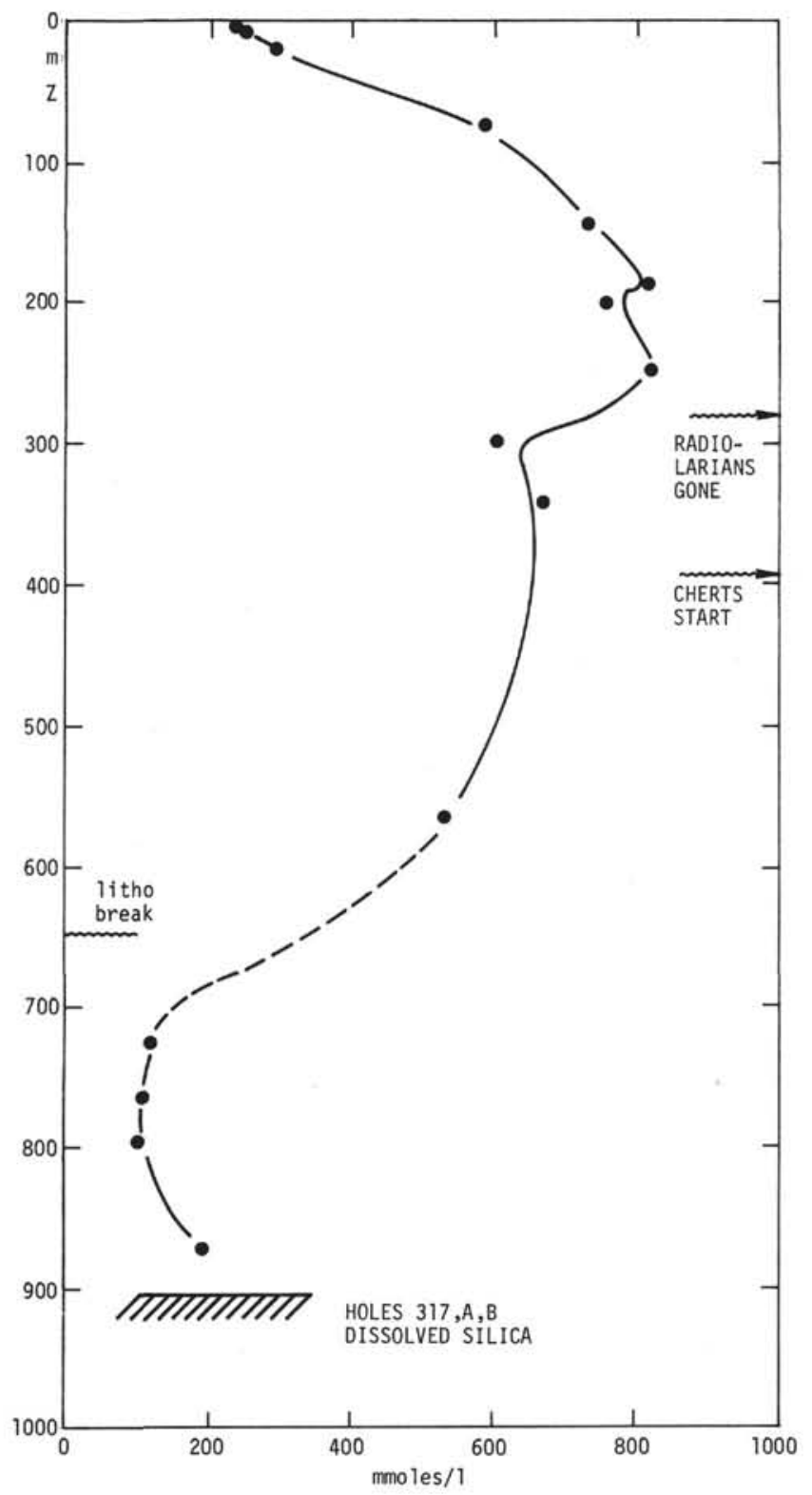

Figure 10. Dissolved silica, Site 317.

larger extent. Such observations can be best understood in terms of the influence of sedimentation rates on the overall diffusional migration processes.

I suggest that sedimentation rates have a very definite influence on the interstitial water profiles, probably due to different influences on diffusional migration processes. The conclusions reached by Sayles and Manheim (1975) on the enhanced influence of bacteriological decomposition reactions on reaction rates in the sediments are open to question, but this problem cannot be entirely resolved by the present study. We plan some simple diffusion-advectionreaction models to study this in greater detail.

\section{ACKNOWLEDGMENTS}

The author acknowledges the careful work of the shipboard chemist, Mr. Jim Pine. Mr. Guntwin Galeisky was helpful in 


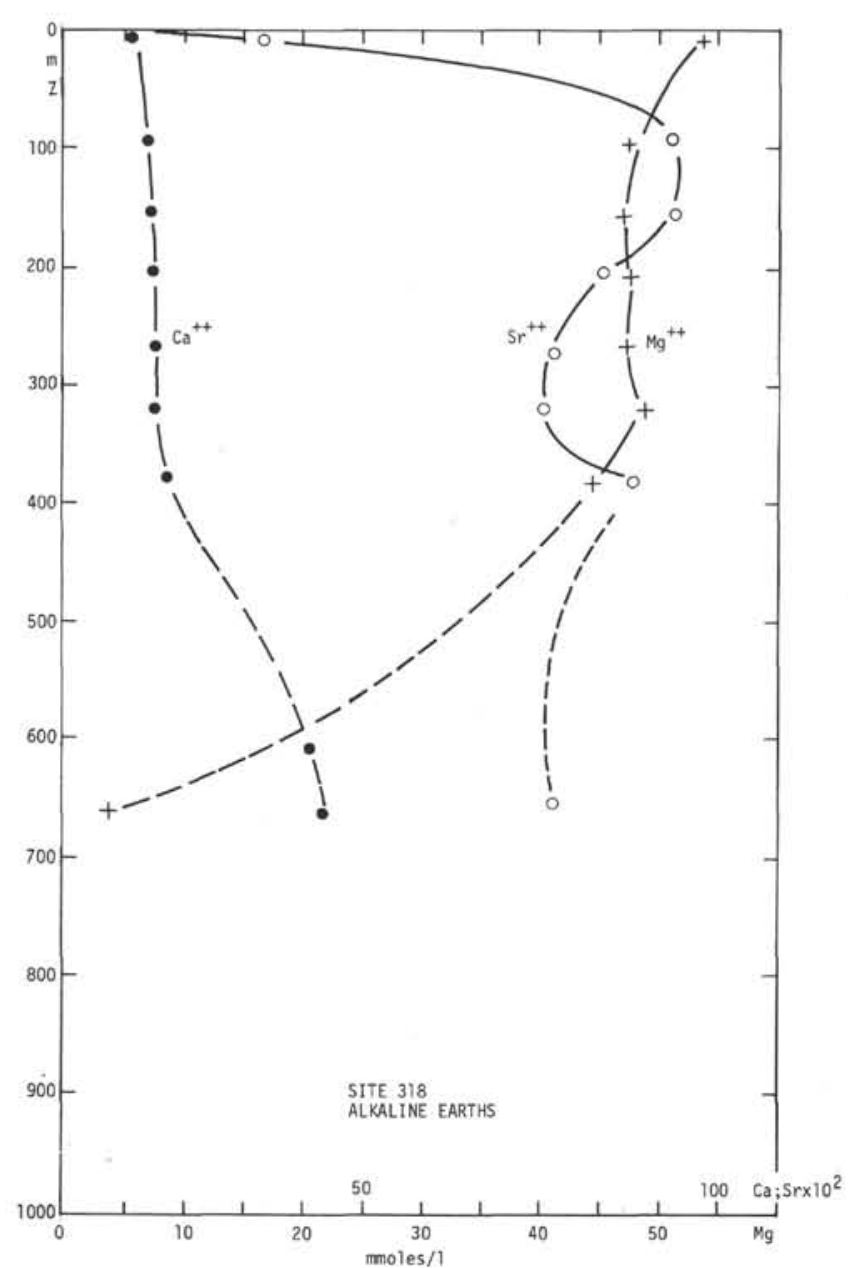

Figure 11. Alkaline earths, Site 318.

some of the chemical analyses. This research was generously supported by NSF Grant GA-33229.

\section{REFERENCES}

Bass, M.N., Moberly, R., Rhodes, J.M., Shih, C., and Church, S.E., 1973. Volcanic rocks cored in the Central Pacific, Leg 17, Deep Sea Drilling Project. In Winterer, E.L., Ewing, J.I., et al., Initial Reports of the Deep Sea Drilling Project, Volume 17: Washington (U.S. Government Printing Office), p. 429-503.

Church, T.M. and Wolgemuth, K., 1972. Marine barite saturation: Earth Planet Sci. Lett., v. 15, p. 35-44.

Gieskes, J.M., 1973. Interstitial water studies, Leg 15: Alkalinity, $p \mathrm{H}, \mathrm{Mg}, \mathrm{Ca}, \mathrm{Si}, \mathrm{PO}_{4}$ and $\mathrm{NH}_{4}$. In Heezen, B.C., MacGregor, I., et al., Initial Reports of the Deep Sea Drilling Project, Volume 20: Washington (U.S. Government Printing Office), p. 813-829.

1974. Interstitial water studies, Leg 25. In Simpson, E.S.W., Schlich, R., et al., Initial Reports of the Deep Sea Drilling Project, Volume 25: Washington (U.S. Government Printing Office), p. 361-394.

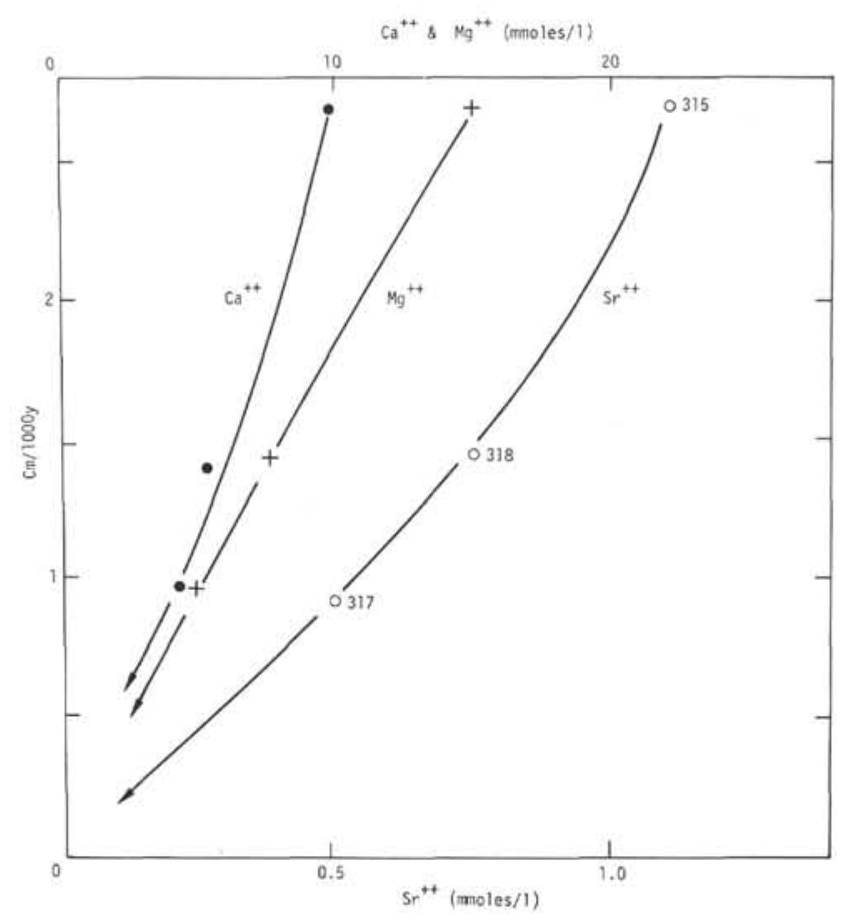

Figure 12. Sedimentation rate versus changes in alkaline earths, Sites 315,317 , and 318.

Gieskes, J.M. and Rogers, W.C., 1973. Alkalinity determination in interstitial waters of marine sediments: J. Sediment Petrol., v. 43, p. 272-277.

Gieskes, J.M., Kastner, M., and Warner, T.B., in press. Evidence for extensive diagenesis, Madagascar Basin, Deep Sea Drilling Site 245: Geochim. Cosmochim. Acta.

Lawrence, J.R., Gieskes, J.M., and Broecker, W.S., in press. Oxygen isotope and cation composition of DSDP pore waters and the alteration of Layer II basalts: Earth Planet Sci. Lett.

Lerman, A., 1975. Maintenance of steady state in oceanic sediments: Am. J. Sci., v. 275 , p. 609-635.

Li, Y.-H. and Gregory, S., 1974. Diffusion of ions in sea water and in deep sea sediments: Geochim. Cosmochim. Acta, v. 38 , p. 703-714.

Manheim, F.T. and Sayles, F.L., 1974. Composition and origin of interstitial waters of marine sediments, based on deep sea drilling cores. In The sea, Vol. 5 Goldberg, E.D. (Ed.), Chapter 16: New York (Wiley-Interscience).

Muffler, L.J.P., Short, J.M., Keith, T.E.C., and Smith, V.C., 1969. Chemistry of fresh and altered basaltic glass from the upper Triassic Hound Island volcanics, southeastern Alaska: Am. J. Sci., v. 267, p. 196-209.

Sayles, F.L. and Manheim, F.T., 1975. Interstitial solutions and diagenesis in deeply buried marine sediments: results from the Deep Sea Drilling Project: Geochim. Cosmochim. Acta, v. 39, p. 103-127.

Sholkovitz, F.R., 1973. Interstitial water chemistry of the Santa Barbara Basin sediments: Geochim. Cosmochim. Acta, v. 37 , p. $2043-2073$. 